RECORDS ADMINISTRATION

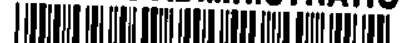

R1072367

DPST-89-248

FUEL PERFORMANCE COMPARISON BETWEEN SAVANNAH RIVER REACTORS AND THE U. S. COMMERCIAL NUCLEAR REACTORS

JANUARY 1988

Patent Status

This Internal management report is being transmitted without DOE patent clearance, and no further dissemination or publlcation shall be made of the report without prlor approval of the DOE-SR patent counsel.

E. I. du Pont de Nemours \& Co. Savannah River Laboratory Aiken, SC 29808 


\section{DISCLAIMER}

This report was prepared by E. I. du Pont de Nemours and Company (DuPont) for the United States Dopartment of Enorgy under Contract DE-ACO9-76SA00001 and is an account of work porformed under that Contract. Nolther the United States, the United States Department of Energy nor Du Pont, ner smy of thelit empiojeces, makes any warranty, exproses or implied, or assumes any legal liablitty or responslbilty for the accuracy, comploteness, or usefulness of any information, apparatus, product, or proceses dlaclosed hereln, or represents that lts use will not infringe prlvately owned rights. Roforence herein to any specifle commerclal product, process or service by trade name, mark, manufacturer, or otherwles does not necessarily constitute or Imply endorsement, recommendation, or fevoring of same by Du Pont or by the United States Government or any agency thereof. The vlows and opinlons of authors expreseed heroln do not necesearily state or refiect those of the United States Government or any agency thereof. 
NUCLEAR REACTOR TECHNOLOGY

AND SCIENTIFIC COMPUTATIONS

KEY WORDS: REACTOR SAFETY

FUEL PERFORMANCE

COMPARISON

COMMERCIAL REACTORS

RETENTION: LIFETIME

\title{
FUEL PERFORMANCE COMPARISON BETWEEN SAVANNAH RIVER REACTORS AND THE U. S. COMMERCIAL NUCLEAR REACTORS
}

\author{
By \\ I. K. PAIK \\ AND \\ P. G. ELLISON
}

ISSUED: JANUARY 1989

SRL SaVANNAH RIVER Laboratory, AIKEN, SC 29808

E. I. du Pont do Nemours \& Company, Inc.

Prepared for the U. S. Department of Energy Under Contract DE-ACO9-76SR00001 
DOCUMENT: DPST-89-248

TITLE:

FUEL PERFORMANCE COMPARISON BETWEEN SAVANNAH RIVER REACTORS AND THE U. S. COMMERCIAL NUCLEAR REACTORS

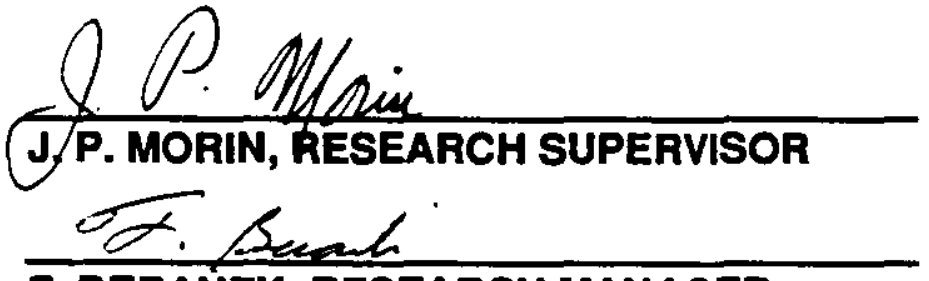

F. BERANEK, RESEARCH MANAGER M.V. Aregory
DATE: $1 / 23 / 89$

DATE: $1 / 30 / 89$

DATE: $1 / 18 / 89$ 


\section{INTRODUCTION}

A review of fuel/target performance of the Savannah River Reactors is made to compare their in-core performance with that of the commercial nuclear reactors in the U.S.

\section{SUMMARY}

The following conclusions on the SRP fuel/target performance are drawn from this review.

1) The SRP fuel/target performance is comparable to that of the commercial nuclear reactor fuels in terms of in-core fuel reliability level.

2) Fuel/target reliability level for SRP has improved significantly since1971 from that of pre-1971 period.

3) Increase in coolant activity level due to fuel/target failures has been controlled by the coolant (or moderator) purification system without having extended reactor shutdown periods for cleanup or releasing any radioactivity to the environment.

\section{DISCUSSION}

The data on fuel performance of commercial nuclear reactors are available through "Fuel Performance Annual Reports" (References 1 - 9). The NRC requires the nuclear power plant licensees to report whether the plant including principal safety barriers (i.e., fuel cladding, reactor coolant system boundary, or containment) was seriously degraded or experienced an unanalyzed condition. As a part of this report, fuel vendors have provided their fuel operating experience to the NRC, and the NRC annually publishes brief summaries of fuel design changes, fuel surveillance programs, fuel operating experience, fuel problems, high-burnup fuel experience, and items of general significance. The fuel performance data of the commercial nuclear reactors used in this comparison are from those annual reports. 
The fuel/target performance data of the Savannah River reactors were obtained from References 10 and 11 and also from searching through the Reactor Incident Reports.

It should be pointed out that due to some of the differences in fuel assembly design and their operating environment between these reactors, as listed below, a direct comparison is difficult.

1) Difference in cladding material (zircaloy tube vs. aluminum tube or slug)

2) Difference in fuel rod geometry (rod vs. annular tube)

3) Reactor operating condition (high temperature \& pressure vs. low temperature \& pressure)

4) Burnup difference

5) Length of fuel cycle

Therefore, this memo only presents a summany of in-core fuel performance in terms of Euel Reliability_evel which is a measure of in-core fuel failure rate as defined in Table 1.

Table 1 shows that generally the commercial nuclear fuel reliability levels are about $99.9 \%$ or greater. The SRP fuel reliability level is about the same as that of commercial reactor fuels. The operating procedures for SRP reactors require the reactor to be shutdown to discharge any failed assembly when it is detected. Commercial reactors are allowed to be continuously operated if the coolant activity level is below the Technical Specification limit. However, the increased coolant activity level due to fission products released through the failed cladding is usually reduced by the coolant purification system for both commercial nuclear reactors and the SRP reactors. There has been no impact on public health or safety from the failures incurred during normal operation in either SRP or commercial nuclear reactors.

Tables 2 and 3 show the major fuel failure mechanisms for commercial reactor fuels and SRP reactor fuel/target, respectively. The current major contributor to commercial nuclear fuel failure is an external cause such as debris-induced fretting wear. By definition, such failures are not factored into the computation of the fuel reliability level. Failures due to the other causes have been reduced by design and fabrication process improvements. 
The major causes of the SRP reactors' fuel/target failures are manufacturing defects such as poor bonds or pin-holes in the weld closure. On one occasion, an error in the BOSF (burnout safety factor) calculation led to a number of target failures which resulted in local burnout of some of the cladding and target material. Reference 10 indicates that most of the failures occurred before 1971, and most of them are slug failures rather than fuel or target tube failures.

Based on this review, the following conclusions can be drawn for the SRP fuel/target performance.

1) The SRP fuel/target performance is comparable to that of the commercial nuclear reactor fuels in terms of in-core fuel reliability level.

2) Fuel/target reliability level for SRP has improved significantly since 1971 from that of pre-1971 period. (Less than 20 percent of the total number of failures occurred since 1971.)

3) Increase in coolant activity level due to fuel/target failures has been controlled by the coolant (or moderator) purification system without having extended reactor shutdown periods for cleanup or releasing any radioactivity to the environment. 
(a)

\section{Table 1. Fuel Reliability Levels}

Total Number of Rods

Euel Vendor Irradiated up to $1985\left(10^{6}\right)$

(b)

B\&W

CE

Exxon

GE

(c)

W

SRP
1.2

0.9

1.1

2.8

4.2

(d)
Fuel Reliability Level

Between 1983 and 1985

$99.990 \%-99.996 \%$

$99.98 \%-99.996 \%$

$99.994 \%-99.998 \%$

$>99.99 \%$

$99.996 \%-99.999 \%$

(d)

Note: (a) Reliability Level is defined as [100 - 100 * (number of failed rods/total number of rods irradiated in cores)]. These do not include any fuel failures due to external causes such as baffle-jetting, debris-induced fretting, and other off-normal core conditions.

(b) TMI-2 data are not included.

(c) For Westinghouse fuel, the reliability level is estimated by using coolant activity (131) level of $5 \times 10^{-4} \mu \mathrm{Ci} /$ gram per failed rod.

(d) $15.3 \times 10^{6}$ fueVtarget tubes and slugs have been irradiated during 124 reactor operating years between 1953 and 1988 . The SRP fuel and target reliability level is for the period between 1953 and 1988 . The rellability levels for the commercial nuclear reactors during 1960 s and 1970 s are not available. 
Table 2. Major Failure Mechanisms of Commercial Nuclear Reactor Fuels

1. Internal contamination (internal zirconium hydriding due to hydrogenous impurity such as moisture introduced during fabrication).

2. Manufacturing defects (defective material, welding flaws, enrichment mixup).

3. Mechanical damage " (fuel mishandling, debris-induced fretting wear).

4. Fuel cladding interactions (pellet-clad interaction due to rapid local power change).

5. Accelerated corrosion (heavy buildup of crud scale that caused the cladding surface to overheat to abnormally high temperatures).

6. Fuel rod bowing (fuel rod bowing due to rod growth by irradiation).

7. Cladding collapse (cladding collapses due to in-core densification of fuel or unpressurized fuel rod).

8. Baffle jetting (vibration induced by coolant jets from baffle).

* Note : Fuel failures caused by these failure mechanisms are not included in the fuel reliability level calculation. 
Table 3. Major Failure Mechanisms of SRP Reactor Fuels and Taroets

1. Defective fabrication (poor bond or nonbond at weld closure of cladding, pin-holes within weld closure, marred cladding surface, improper heat treatment).

2. Corrosion of cladding.

3. Grain growth within uranium metal during irradiation.

4. Incorrect burnout safety factor calculation (power-flow mismatch due to error in burnout safety factor calculation).

Note : The SRP fuel/target reliability level was calculated based on all the failures caused by the failure mechanisms listed above including some unknown causes. 


\section{REFERENCES}

1. NUREG-0032 (1974)

2. NUREG-0633 (1978)

3. NUREG/CR-1818 (1979)

4. NUREG/CR-2410 (1980)

5. NUREG/CR-3001 (1981)

6. NUREG/CR-3602 (1982)

7. NUREG/CR-3950 Vol. 1 (1983)

8. NUREG/CR-3950 Vol. 2 (1984)

9. NUREG/CR-3950 Vol. 3 (1985)

10. Memo by A. J. Renwick, "FUEL AND TARGET FAILURES DURING IRRADIATION", Oct. 28, 1988.

11. Memo by A. J. Renwick, "FUEl AND TARget IRRADIATION", Nov. 8, 1988. 